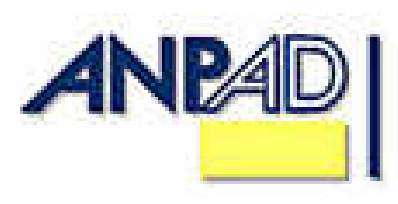

Available online at

http://www.anpad.org.br/bar

\title{
Managing Trust Relationships: Calculative, Affective, Belief and Performance
}

\section{Danny Pimentel Claro *}

E-mail address: danny@isp.edu.br

Ibmec São Paulo

São Paulo, SP, Brazil.

\section{Priscila B. Oliveira Claro}

E-mail address: priscilaboc@isp.edu.br

Ibmec São Paulo

São Paulo, SP, Brazil.

\begin{abstract}
There is an ongoing concern among managers and scholars: how can firms develop trust and achieve performance? Our paper aims to review the emerging perspective of trust and propose mechanisms to build trust in channel relationships. In the literature, we identified six mechanisms: calculative, affective, belief, embeddedness, continuity and capability. A central hypothesis focuses on the direct impact of these mechanisms on firm performance. We conducted a survey $(n=132)$ in the Brazilian Distribution Market of agrochemical products. OLS regression estimation was employed to test the hypothesis. Results show the impact of the mechanisms of calculative, affective, belief on performance. The findings highlight that, even though environment leads to suspicion and doubts, managers seek trust relationships and try to develop them using a combination of few mechanisms to overcome difficulties and perform well.
\end{abstract}

Key words: trust; channel relationship; performance.

Received 12 October 2007; received in revised form 04 August 2008.

Copyright (C) 2008 Brazilian Administration Review. All rights reserved, including rights for translation. Parts of this work may be quoted without prior knowledge on the condition that the source is identified.

* Corresponding author: Danny Pimentel Claro

Business School Ibmec São Paulo, Rua Quatá, 300, Vila Olímpia, São Paulo, SP, 04546-042, Brazil. 


\section{INTRODUCTION}

Trust in the relationship between manufacturer and supplying companies seems essential for their business success. Rapidly changing competitive environments are forcing managers to seek more creative and flexible means for facing competition. In the literature, we see reports claiming that many firms have responded to these challenges by developing trust in collaborative relationships with their distribution channels. Trust operates as a governance mechanism that allows companies to share information and that mitigates opportunism in exchange contexts characterized by uncertainty and dependence. By using trust, firms can reduce the transaction costs associated with monitoring, contracting and punishing opportunistic behavior.

The question that may be addressed in this context is: how can firms develop trust and achieve high performance? In this line of thought, our paper aims to review the literature to identify mechanisms to build up trust. We base our study on the emerging marketing and management literature on trust. Following this aim, our paper intends to elaborate a central hypothesis about trust and performance.

A survey in the agrochemical industry has been conducted in order to collect and test a model to develop trust. Agrochemical products (e.g. fungicide and insecticide) are used by growers in their agricultural production. Growers purchase products from agrochemical distributors who also offer after sales technical assistance to the growers. Agrochemical distributors play a critical role in the selling and supporting activities because the products are toxic and require care in the production process. Distributors purchase agrochemicals from manufacturers who are keen to develop close relationships with them. The relationship between manufacturers and distributors appears to be an interesting relationship when it comes to studying trust. For growers to use agrochemical products in a proper way, distributors have to be working closely with manufacturers. This relationship with manufacturers allows distributors to offer growers the best technical support throughout the use of the product in order to be efficient and avoid any harm to human beings and the environment.

\section{EMERGing Perspective ON TRUST}

Trust is the extent to which negotiations are fair and commitments are sustained (Anderson \& Narus, 1990). The need for trust between partners has been identified as an essential element of buyersupplier relationships (Anderson \& Narus, 1990; Geyskens, Steenkamp, \& Kumar, 1998; Rousseau, Sitkin, Burt, \& Camerer, 1998). Previous research had shown that trust is a basic requirement in the context of buyer-supplier relationships (Morgan \& Hunt, 1994). According to Ring and Van de Ven (1992), trust plays a key role in any organizational relationship. Trust enables partners to manage risk and opportunism in transactions (Nooteboom, Berger, \& Noorderhaven, 1997). There is an element of trust in every transaction, although it varies across the transacting partners (Arrow, 1973). Moreover, trust helps to reduce complex realities more quickly and economically than prediction, authority or bargaining (Powell, 1990).

Trust is a key concept in many research fields, as reflected, for example, in the marketing channels literature (Anderson \& Narus, 1990; Anderson \& Weitz, 1989; Doney \& Cannon, 1997; Ganesan, 1994; Morgan \& Hunt, 1994), organizational decision making (Zand, 1972), network literature (Coleman, 1988; Jarillo, 1988; Larson, 1992; Powell, 1990; Thorelli, 1986; Uzzi, 1997), transaction cost economics (Williamson, 1993; Zajac \& Olsen, 1993; Zylbersztajn \& Zuurbier, 1999), within individuals in team works (Adler, 2007; Lewicki, Mcallister, \& Bies, 1998), public trust (Herder \& Brian, 2008) and psychology (Rotter, 1971, 1980). Each of these schools of thought uses a different definition of trust. Building on Geyskens et al. (1998) compilation of definitions of trust, we have developed our own compilation that includes the network and other research traditions (Table 1). 
Table 1: Representative Literature on Trust

\begin{tabular}{|c|c|c|c|}
\hline Study & $\begin{array}{l}\text { Research } \\
\text { Tradition }\end{array}$ & Unit of Analysis & Conceptualization of Trust \\
\hline $\begin{array}{l}\text { Anderson and } \\
\text { Weitz (1989) }\end{array}$ & $\begin{array}{l}\text { Marketing } \\
\text { channels }\end{array}$ & $\begin{array}{l}\text { Sales } \\
\text { representative } \\
\text { and their } \\
\text { suppliers }\end{array}$ & $\begin{array}{l}\text { A firm's belief that its needs will be fulfilled in the } \\
\text { future by actions undertaken by their partner. }\end{array}$ \\
\hline $\begin{array}{l}\text { Anderson and } \\
\text { Narus (1990) }\end{array}$ & $\begin{array}{l}\text { Marketing } \\
\text { channels }\end{array}$ & $\begin{array}{l}\text { Distributors and } \\
\text { their } \\
\text { manufacturers }\end{array}$ & $\begin{array}{l}\text { A firm's belief that partners will perform actions that } \\
\text { will result in positive outcomes for the firm and will } \\
\text { not take unexpected actions that would result in } \\
\text { negative outcomes for the firm. }\end{array}$ \\
\hline $\begin{array}{l}\text { Barney and } \\
\text { Hansen (1994) }\end{array}$ & Management & Organizations & $\begin{array}{l}\text { The mutual confidence that no party in an exchange } \\
\text { will exploit another's vulnerabilities. }\end{array}$ \\
\hline $\begin{array}{l}\text { Bradach and } \\
\text { Eccles (1989) }\end{array}$ & Management & Organizations & $\begin{array}{l}\text { The positive expectation that reduces the risk that } \\
\text { the exchange partner will act opportunistically. }\end{array}$ \\
\hline $\begin{array}{l}\text { Ganesan (1994) } \\
\text { and Doney and } \\
\text { Cannon (1997) }\end{array}$ & $\begin{array}{l}\text { Marketing } \\
\text { channels }\end{array}$ & $\begin{array}{l}\text { Vendors and } \\
\text { retail buyers }\end{array}$ & $\begin{array}{l}\text { The belief that the partner is credible and } \\
\text { benevolent. }\end{array}$ \\
\hline $\begin{array}{l}\text { Granovetter } \\
\text { (1985) }\end{array}$ & Networks & Organizations & Confidence in the general morality of individuals. \\
\hline Gulati (1995) & Networks & $\begin{array}{l}\text { Biopharmaceutic } \\
\text { al, automotive, } \\
\text { new materials } \\
\text { suppliers and } \\
\text { buyers }\end{array}$ & $\begin{array}{l}\text { The particular level of subjective probability with } \\
\text { which agents assess whether another agent or group } \\
\text { will perform a particular action both before they } \\
\text { can monitor such action and in a context in which it } \\
\text { affects their own action. }\end{array}$ \\
\hline $\begin{array}{l}\text { Hakansson and } \\
\text { Snehota (1995) }\end{array}$ & Networks & Organizations & $\begin{array}{l}\text { A context in which the probability that a partner will } \\
\text { perform an action that is beneficial or at least not } \\
\text { detrimental to the counterpart is sufficiently high as } \\
\text { to consider engaging in some form of cooperation. }\end{array}$ \\
\hline $\begin{array}{l}\text { Klein, Rai and } \\
\text { Straub (2007) }\end{array}$ & Supply Chain & Logistics firms & $\begin{array}{l}\text { An integrated model of organizational trust, focusing } \\
\text { on beliefs: ability, benevolence and integrity. }\end{array}$ \\
\hline $\begin{array}{l}\text { Kumar, Scheer } \\
\text { and Steenkamp } \\
(1995)\end{array}$ & $\begin{array}{l}\text { Marketing } \\
\text { channels }\end{array}$ & $\begin{array}{l}\text { Car dealers and } \\
\text { car manufacturer }\end{array}$ & The belief that the partner is honest and benevolent. \\
\hline $\begin{array}{l}\text { Morgan and } \\
\text { Hunt (1994) }\end{array}$ & $\begin{array}{l}\text { Marketing } \\
\text { channels }\end{array}$ & $\begin{array}{l}\text { Independent } \\
\text { retailers and } \\
\text { their suppliers }\end{array}$ & Confidence in the partner's reliability and integrity. \\
\hline Powell (1990) & Networks & Organizations & $\begin{array}{l}\text { Confidence translated into the act of taking as } \\
\text { certain those critical aspects of life which in a } \\
\text { business environment are rendered uncertain. }\end{array}$ \\
\hline $\begin{array}{l}\text { Rotter (1971, } \\
\text { 1980) }\end{array}$ & Psychology & Individuals & $\begin{array}{l}\text { A generalized expectancy held by an individual that } \\
\text { the work, promise or statement of another } \\
\text { individual can be relied on. }\end{array}$ \\
\hline $\begin{array}{l}\text { Sitkin and Roth, } \\
\text { (1993) }\end{array}$ & Management & $\begin{array}{l}\text { Organizations } \\
\text { and individuals } \\
\text { in the medical } \\
\text { industry }\end{array}$ & $\begin{array}{l}\text { The belief, attitude or expectation that the actions or } \\
\text { outcomes of another individual or organization will } \\
\text { be acceptable or will serve the partner's interest. }\end{array}$ \\
\hline $\begin{array}{l}\text { Thorelli (1986) } \\
\text { and Jarillo (1988) }\end{array}$ & Networks & Organizations & $\begin{array}{l}\text { An assumption or reliance on the part of A that if } \\
\text { either A or B encounters a problem in the } \\
\text { fulfillment of implicit or explicit transactional } \\
\text { obligations, B may be counted on to do what A } \\
\text { would do if B's resources were at A's disposal. }\end{array}$ \\
\hline
\end{tabular}


(conclusion)

Table 1: Representative Literature on Trust

\begin{tabular}{|c|c|c|c|}
\hline Study & $\begin{array}{l}\text { Research } \\
\text { Tradition }\end{array}$ & Unit of Analysis & Conceptualization of Trust \\
\hline Uzzi (1997) & Networks & $\begin{array}{l}\text { Apparel stores } \\
\text { and their } \\
\text { suppliers }\end{array}$ & $\begin{array}{l}\text { The belief that an exchange partner would not act in } \\
\text { self-interest at another's expense and operates not } \\
\text { like calculated risk but like a heuristic - a } \\
\text { predilection to assume the best when interpreting } \\
\text { another's motives and actions. }\end{array}$ \\
\hline $\begin{array}{l}\text { Williamson } \\
\text { (1993) }\end{array}$ & $\begin{array}{l}\text { Transaction } \\
\text { cost } \\
\text { economics }\end{array}$ & Organizations & $\begin{array}{l}\text { The rational form of trust fostered by mutual } \\
\text { hostages, and building on reputation effects and } \\
\text { risk. }\end{array}$ \\
\hline $\begin{array}{l}\text { Zaheer, McEvily } \\
\text { and Perrone } \\
\text { (1998) }\end{array}$ & Management & $\begin{array}{l}\text { Electrical and } \\
\text { electronic } \\
\text { equipment } \\
\text { manufacturers }\end{array}$ & $\begin{array}{l}\text { The leap of faith by placing confidence in a referent } \\
\text { without knowing with absolute certainty that the } \\
\text { referent's future actions will not produce unpleasant } \\
\text { surprises. }\end{array}$ \\
\hline $\begin{array}{l}\text { Zaheer and } \\
\text { Venkatraman } \\
\text { (1995) }\end{array}$ & $\begin{array}{l}\text { Transaction } \\
\text { cost } \\
\text { economics }\end{array}$ & $\begin{array}{l}\text { Agency and } \\
\text { insurance } \\
\text { representative }\end{array}$ & $\begin{array}{l}\text { The extent to which negotiations are fair and } \\
\text { commitments are upheld. Trust is a } \\
\text { multidimensional concept, significantly developed } \\
\text { on affective behavioral and cognitive bases. }\end{array}$ \\
\hline Zand (1972) & Management & $\begin{array}{l}\text { Individual } \\
\text { managers }\end{array}$ & $\begin{array}{l}\text { Actions that (a) increase one's vulnerability, (b) to } \\
\text { another whose behavior is not under one's control } \\
\text { (c) in a situation in which the penalty (disutility) } \\
\text { one suffers if the other abuses that vulnerability is } \\
\text { greater than the benefit (utility) one gains if the } \\
\text { other does not abuse that vulnerability. }\end{array}$ \\
\hline
\end{tabular}

Based on Geyskens et al. (1998, p. 226).

Before discussing the central hypothesis of this study, we introduce the mechanisms to build up trust.

\section{Mechanisms to Build up Trust}

As Table 1 shows, significant differences in assumptions and methods exist between behaviorally oriented and economically oriented organizational scholars (Barney, 1991). On the one hand, behaviorally oriented researchers argue that most exchange partners are trustworthy, that they behave as stewards over the resources under their control and thus that trust in an exchange relationship even without legal and contractual safeguards - will become common (Das \& Teng, 1998). On the other hand, economically oriented scholars respond that it is difficult to distinguish at first between exchange partners that are actually trustworthy and those that only claim to be trustworthy (Williamson, 1993). This limits the scope of trust to that within rational prediction or calculation, wherein partners focus on collecting and processing information to forecast likely outcomes of certain future events (Doney \& Canon, 1997). Although rational prediction is clearly an important part of trust, it provides a grossly incomplete understanding of trust on its own. Moreover, some economists recognize that a degree of trust must be assumed to operate, since formal control mechanisms alone cannot entirely stem force or fraud (Akerlof, 1970; Klein, 1996). Following this current theoretical discussion, six mechanisms to build trust may be considered in a model to study trust. The proposed six mechanisms are shown in Figure 1. 


\section{Figure 1: Six Mechanisms of Trust}

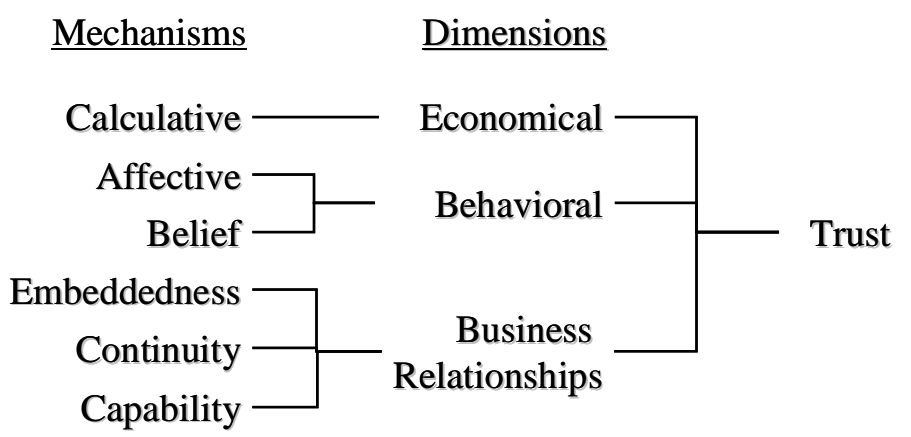

First, the economic literature suggests that trust primarily involves a calculative process (Williamson, 1996). To the extent that the benefits of cheating do not exceed the costs of being caught, the buyer infers that it would be contrary to the supplier's best interest to cheat, and so the supplier can be trusted (Akerlof, 1970). Therefore, managers have to be able to calculate the costs and rewards of another party cheating or cooperating in a relationship.

Following Wicks, Berman and Jones (1999), we identify two behavioral characteristics that complement the calculative mechanism, namely affection and belief. Affection is an emotion felt by people in a relationship (Rotter, 1980). Trust occurs because an emotional bond is created between individuals, enabling them to move beyond rational prediction to take a leap of faith that trust will be honored (Wicks et al., 1999). Some authors in the marketing channels school view affection-based trust as the benevolence of an individual toward a relationship (Anderson \& Narus, 1990; Morgan \& Hunt, 1994). Benevolence in a partner is motivated by concern for the well-being of the relationship itself and not by the goal of improving own welfare at the expense of the partners' interests (Ganesan, 1994). The affective aspect of trust has a clear moral element and is influenced by the intentions of the other party (Deutsch, 1969). Therefore, managers can interpret the other party's words and actions, and attempt to determine their intentions in the relationship.

The emotional bond in question is not just in the relationship but is, in large part, a belief in the moral character or goodwill of the trustee in the trusting relationship. Through their shared beliefs, partners can create goal congruence and thereby reduce the risk of free-riding and other types of opportunism (Bradach \& Eccles, 1989). In the marketing channels tradition, belief-based trust is described as credibility (Kumar et al., 1995). As trust stems from expectations of how another party will behave based on that party's past and present implicit and explicit claims, a manager needs to forecast another party's behavior.

We have highlighted the affective and belief mechanisms because both are critical to building trust. Rational prediction (calculative mechanism) helps prevent partners from trusting blindly or foolishly. Affection and belief are necessary for developing and sustaining mutually trusting relationships, as well as for realizing the benefits that flow from trust. Thus, the level of trust can range from a degree of affection-based belief in moral character (e.g., having less than a fully effective deterrent, such as mutually assured destruction), extending up to the point at which trust is so complete as to constitute 'blind faith' in the moral character of the other (e.g., that between parent and child). Based on this understanding, a widely accepted definition of trust is the belief, attitude or expectation that the actions or outcomes of another individual, group or organization will be acceptable or will serve the partner's interest (Sitkin \& Roth, 1993).

Although this definition embraces the calculative, affective-based and belief mechanisms of trust discussed previously, for business relationships three other mechanisms require specific elaboration to be included in a model to study trust. Therefore, the fourth mechanism of the trust model is embeddedness. Trust is directly influenced by the network because trust is socially embedded (Granovetter, 1985). Trust exists within a context and is shaped by the dynamics specific to a 
particular social setting (Powell, 1990). Trust can be transferred from a trusted proof source to another individual or group with which the buyer has little or no direct experience (Doney \& Canon, 1997). This transference process allows trust to spread from a known entity to an unknown entity. In his discussion of embeddedness, Granovetter (1985) demonstrated that the models used in classical and neoclassical economics (such as transaction cost economics) are undersocialized and omit the role of concrete personal relations and structures (such as networks). He emphasized the fundamental conceptual inadequacy of undersocialized approaches to trust (i.e., theories not taking embeddedness seriously), particularly for both describing and creating trusting relations.

Fifth, trust is continuous, as opposed to being a static and discrete concept (Das \& Teng, 1998; Wicks et al., 1999), which suggests a continuity mechanism of trust. A partner can both trust and distrust people at the same time (Sitkin \& Roth, 1993). The development of trust relies on the formation of one partner's expectations about the motives and behaviors of another. Furthermore, trust has a wide spectrum, and can vary substantially both within and across relationships, as well as over time. As Bradach and Eccles (1989, p. 108) said,

in dynamic and continuous settings, a record of prior exchange, often obtained secondhand or by imputation from outcomes of prior exchange, provides data on the exchange process. Relationships unfold so that individuals continually update their information base and their decisions to trust.

Finally, trust can be built on the basis of the partners capabilities, which is the sixth mechanism of the trust model. A manager can assess the ability to meet his or her obligations as well as the partner's expectations. Trust as a derivative of technically competent performance ensures partners that desired outcomes can be obtained. In the logistics sector, companies have relied on their ability to exchange information in order to build up trust and achieve performance (Klein et al., 2007). The focus can be turned to the credibility component of trust.

\section{Trust and Performance}

Firms involved in trust relationships are likely to perform well. Trust relationships allow firms to have a shared belief that, in the long run, rewards will be distributed fairly among the partners (Barney \& Hansen, 1994). There is a general sense that this year's winner could be next year's loser and, consequently, to press one's advantage opportunistically would be unadvisable. Trust is an important lubricant of relationships. It binds parties and has an important future orientation (Ganesan, 1994). Previous studies have found that trust guides behavior in some business settings (Doney \& Cannon, 1997; Morgan \& Hunt, 1994), and when trust is operative the risk of opportunism and market instability is reduced. Moreover, Smith and Barclay (1997) found that trust significantly affects the attitudes and behavior of suppliers toward buyers (i.e., independent sellers).

A high degree of trust between the partners in a business relationship is conducive to coordinative behavior. This assertion follows the findings of Anderson and Narus (1990) and Gulati (1995). Trust encourages effective communication, information sharing and joint pay-offs (Dwyer, Schur, \& Oh, 1987, Ring \& Van de Ven, 1992) and might create a strong social bond (Barney \& Hansen, 1994). Therefore, trust significantly reduces the perception of risk associated with opportunistic behavior by a partner; it increases confidence that short-term inequities will be resolved in the long term and reduces the transaction costs in an exchange relationship (Ganesan, 1994). Our assumption is that the higher the level of the six mechanisms to build trust, the higher the level of trust there will be in a relationship. Therefore, we expect that the higher the degree of the six mechanisms to build trust, the higher the performance of the company. Our central hypothesis may be stated as:

Central Hypothesis: The greater the level of the trust mechanisms $\left(H_{a}\right.$ : calculative, $H_{b}$ : affective, $H_{c}$ : belief, $H_{d}$ : embeddedness, $H_{e}$ : continuity and $H_{f}$ : capability), the higher the firm's performance.

In this study, we have included three control variables. Previous research suggests that the buyersupplier relationship might be affected by the firm's size (Lusch \& Brown, 1996; i.e. turnover and size 
of the sales force) and dependency (Lusch \& Brown, 1996). We do not specify hypotheses for each of the control variables, although we do expect a positive relationship between firm size and performance. In addition, we expect a negative relationship between dependency and performance. The model is shown in Figure 2.

Figure 2: The Model of Trust and Performance

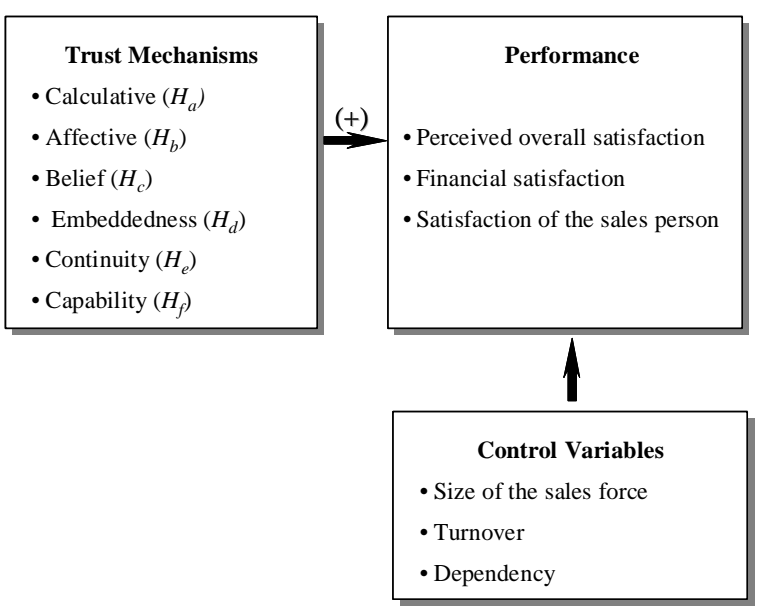

\section{METHODOLOGY}

\section{Data Collection}

The data were collected in the year 2005 in Brazil. Every year, one of the largest agrochemical manufacturers promotes an annual meeting to gather all of its distributors. With the agreement of this agrochemical manufacturer, we presented the research project and invited distributors to fill in the questionnaires. There were over 300 distributors on site from all over Brazil. After excluding nonqualifying distributors (e.g., foreign companies), the data collection effort yielded 158 responses from distributor companies, of which 26 were incomplete questionnaires. Our data collection effort resulted in 132 usable questionnaires with a $67 \%$ response rate. The sample demographics reflect a diverse representation of respondents' distributors. Table 2 displays a frequency table of the number of respondent in each location - national region of the Brazilian states - of the distributors' head office.

Table 2: Descriptive Statistics by Regions of States

\begin{tabular}{lcc}
\hline Regions of States & Frequency & Percentage \\
\hline South & 47 & 35.6 \\
Mid West & 42 & 31.8 \\
Southeast & 28 & 21.2 \\
Northeast & 11 & 8.3 \\
North & 4 & 3.0 \\
\hline Total & 132 & 100.0 \\
\hline
\end{tabular}

A self-administered questionnaire was used consisting of 42 pre-coded questions. For most of the items, the Likert 5-point response format was used, and a limited number of items were assessed with 2 to 5-point response formats. When responding to the questions about the mechanisms of trust and 
performance, informants were asked to consider their relationship with the most important agrochemical producer.

Before starting the data collection, we tested the questionnaire in a panel, the panel being made up of faculty members and industry experts. This was particularly helpful in order to create the different measurement scales and individual items. The panel helped improve the wording of some questions and also provided information to develop a list of concepts and definitions, which was included in the introduction letter of the questionnaire.

\section{Research Instrument}

Trust in operational terms refers to the belief that the other partner is honest and sincere and in no circumstances will deliberately do anything that will damage the relationship. Trust is also embodied in a partner's belief that its requirements will be fulfilled through future actions undertaken by their counterpart (Anderson \& Weitz, 1989; Barney \& Hansen, 1994). We operationalized trust in six mechanisms to build it up. The measure to the calculative dimension refers to the activities to calculate costs and rewards (Crombach $\alpha=.73$ ). We used 2 items: "sales in relation to the store space allocated for partners' products' and 'Consumer flow given partners' products in the store'. The measure to capture the belief dimension refers to the activities to forecast counterpart's behavior ( $\alpha=$ .76). We used 2 items such as: 'The environment to work with this supplier is pretty good' and 'We get timely and accurate information from this supplier'. The measure to capture the affective dimension refers to the activities to forecast counterpart's intentions $(\alpha=.68)$. We used 2 items such as: 'He/she perfectly understands my needs'. The measure to capture the capability of the partner refers basically to the assessment of the counterpart's ability to meet obligations $(\alpha=.60)$. There were 5 items such as: 'The number of salespeople and technical personnel of the partner assisting us in the business is good' and 'The sales representative of the partner is knowledgeable about the products and has been trained to assist us'. All of the four measures described above were on 5-point Likert scale raging from Not at all to Very Much. The score of each measure was the unweighted average of the corresponding items. We used a 10-point Likert scale to measure the importance of the network to the development of the business relationship. We attempted to capture 4 themes relevant to the companies in the industry concerning competition among distributors of the same agrochemical supplier, competition with other distribution channels, conflict with direct distribution and price setting differences. We decided to maintain the estimation, though this measurement instrument did not perform so well $(\alpha=.58)$. Finally, the measure to capture the continuity dimension of the mechanisms to build up trust refers to an open-ended question as to the number of years that the respondent had done business with the selected agrochemical producer.

This study applies a multidimensional measure of performance with a 5-point Likert scale ranging from not at all satisfied to totally satisfied. We measured the satisfaction of the distributor with the contact person in the selected agrochemical producer. Four items were used for this measure. We also measured satisfaction of the distributor with the profitability and margin of the sales of the products of the selected producer. Two items were used to capture the distributors' perception of the financial results. The score of the performance variable was the unweighted average of the corresponding items. Table 3 shows the items used in the data collection.

Table 3: Items of Likert-scale Constructs

Calculative (5-point Likert scale, not at all-very much) $\alpha=0.73$

The investments made to sell the (name of the manufacturer) products increase consumer traffic in our stores.

The sales of the (name of the manufacturer) products compensates the store space dedicated to this manufacturer.

Affective (5-point Likert scale, not at all-very much) $\alpha=0.76$

. My contact person with the manufacturer perfectly understands my needs.

. We have established a mutual understanding in our relationship. 


\section{(conclusion)}

Table 3: Items of Likert-scale Constructs

\footnotetext{
Belief (5-point Likert scale, not at all-very much) $\alpha=0.68$

. The environment to work with this manufacturer is pretty good.

We get timely and accurate information from this manufacturer.
}

\footnotetext{
Capability (5-point Likert scale, not at all-very much) $\alpha=0.60$

- The commercial, technical and marketing personnel of my manufacturer focus on the products that I sell for them.

- This manufacturer offers an important after sales support to my clients (producers of agriculture products).

. This manufacturer sales approach helps me in selling products.

- The number of salespeople and technical personnel of the manufacturer assisting us in our business is good.

- The sales representative of the manufacturer is knowledgeable about the products and is trained to assist us.
}

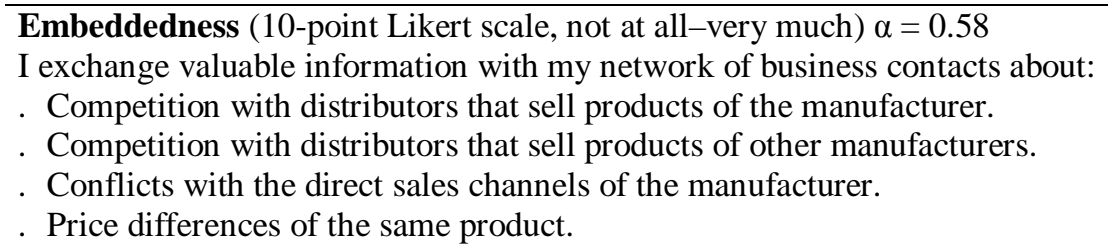

Three control variables were used in the estimation. To measure dependency, we used an openended question as to the percentage of the products comes from the selected producer. We used two measures for firm size. They were the annual turnover of the company and the size of the sales force.

We checked the reliability of our measurement instruments using Cronbach's alpha, composite reliability (> .67), and extracted variance (> .61) of the measures. In all cases Cronbach's alpha was sufficiently high $(>.60)$ to warrant confidence in the internal consistency of the scales, except one measure of the trust mechanism that is about 0.60 . The correlations between the constructs did not suggest problems of pair wise colinearity that would preclude the use of all constructs in one equation (Hair, Anderson, Tatham, \& Black, 1998). Table 4 displays the correlation matrix and descriptive statistics.

Table 4: Correlation and Descriptive

\begin{tabular}{lccccccccccc}
\hline & Mean & SD & 1 & 2 & 3 & 4 & 5 & 6 & 7 & 8 & 9 \\
\hline Performance (1) & 4.01 & 0.57 & 1 & & & & & & & \\
Calculative (2) & 3.76 & 0.60 & $\mathbf{. 4 4}$ & 1 & & & & & & \\
Affective (3) & 3.81 & 0.74 & $\mathbf{. 5 5}$ & $\mathbf{. 3 9}$ & 1 & & & & & \\
Belief (4) & 4.22 & 0.79 & $\mathbf{. 5 8}$ & $\mathbf{. 4 0}$ & $\mathbf{. 3 3}$ & 1 & & & & \\
Capability (5) & 4.32 & 0.46 & $\mathbf{. 4 7}$ & $\mathbf{. 4 1}$ & $\mathbf{. 3 4}$ & $\mathbf{. 5 5}$ & 1 & & & \\
Embeddedness (6) & 5.28 & 2.52 & -.03 & .12 & -.10 & -.07 & -.02 & 1 & & \\
Continuity (7) & 7.39 & 5.60 & -.08 & -.16 & -.10 & -.10 & .00 & .07 & 1 & & \\
Sales force (8) & 9.47 & 8.64 & -.14 & .03 & .00 & .00 & .00 & .15 & .11 & 1 \\
Dependency (9) & 48.13 & 27.80 & .01 & .07 & -.03 & .06 & .11 & .02 & -.19 &.- .32 & 1 \\
Turnover (10) & $2.78 \mathrm{E} 7$ & $4.37 \mathrm{E} 7$ & -.07 & -.02 & -.06 & .06 & .05 & .19 & $\mathbf{. 1 9}$ & $\mathbf{. 3 2}$ & -.02 \\
\hline
\end{tabular}

We conducted a MANOVA Test to evaluate differences in perceptions of the mechanisms to build trust considering the different origin of distributors (i.e. 5 different national regions of Brazilian States $)^{(1)}$. We also conducted a Bonferroni Post Hoc Test to evaluate the difference in performance (Hair et al., 1998). No significant difference was found in our sample, except a difference in perception of calculative mechanism between South and Mid-Western respondents. Despite the great number of estimates (i.e. five mechanisms of trust and the five different national regions), this difference between only 2 regions does not rule out the representativeness of our sample - as one 
might suggest considering the huge geographic expanse of Brazilian territory. Therefore, the test results suggest that the perception of the respondents in our sample are highly generalizable across regions.

\section{RESULTS AND DISCUSSION}

The hypothesis was tested based on Ordinary Least Square Regression ${ }^{(2)}$. Regression analysis is popular among researchers because it allows for an evaluation of the degree (i.e. coefficient size), nature (i.e. coefficient sign) and optimization (i.e. coefficient of determination, $\mathrm{R}^{2}$ ) of association between variables (Hair et al., 1998). By computing the unweighted average of the items reflecting each construct, we regressed the six mechanisms to build trust and the control variables on performance (Table 5). Therefore, our function is specified as follows:

Performance $=\mathbf{f}($ Calculative, Affective, Belief, Capability, Embeddedness, Continuity, Size of Sales Force, Dependency, Turnover)

Tests for multicollinearity showed no problem. The indices lay below the threshold values of 10 for the VIF test and 30 for the Condition index (Hair et al., 1998). The explanatory power of the equation supports the further examination of individual coefficients, to check the effects of each mechanism on performance.

Table 5: Results of the Model Estimation

\begin{tabular}{|c|c|c|}
\hline & Performance & Hypotheses tests \\
\hline Calculative & $280(3.19) * * *$ & $\mathrm{H}_{\mathrm{a}}$ : Confirmed \\
\hline Affective & $.364(4.39) * * *$ & $\mathrm{H}_{\mathrm{b}}$ : Confirmed \\
\hline Belief & $.294(3.34)^{* * * *}$ & $\mathrm{H}_{\mathrm{c}}$ : Confirmed \\
\hline Capability & $.062(.73)$ & $\mathrm{H}_{\mathrm{d}}$ : Rejected \\
\hline Embeddedness & $.048(.72)$ & $\mathrm{H}_{\mathrm{e}}$ : Rejected \\
\hline Continuity & $.017(.25)$ & $\mathrm{H}_{\mathrm{f}}$ : Rejected \\
\hline Size of Sales Force & $-.210(2.79)^{* * * *}$ & \\
\hline Dependency & $-.081(1.09)$ & \\
\hline Turnover & $-.025(.35)$ & \\
\hline Adjusted $\mathbf{R}^{2}$ & $.628 * * *$ & \\
\hline
\end{tabular}

There are several positive significant effects of the mechanisms of trust on performance. The results show that calculative mechanism influences positively performance $(\beta=.28, p<.001)$, which is in line with our hypothesis $\left(\mathrm{H}_{\mathrm{a}}\right)$. This suggests that the distributors created an estimation process in which the costs of a manufacturer acting in an untrustworthy manner are quite high for firms with a good reputation. Manufacturers send strong positive signals when they consistently deliver on their promises to others. Without delivering on their promises, it is hard for them to maintain a preferred 
position in the market. By assessing carefully the gains and losses of developing a trust relationship, the distributor does not expect any opportunistic behavior from its manufacturer.

The affective mechanism to build trust also influences performance positively $(\beta=.36, \mathrm{p}<.001)$, as hypothesized $\left(\mathrm{H}_{\mathrm{b}}\right)$. The distributor that is able to interpret the counterpart's intentions performs well. The distributors need to develop an accurate assessment of buyers' interests and values. The manufacturer that holds common goals and policies are able to sign similar intentions. The moral element plays an important role in the relationship and may allow distributors to better forecast longterm actions of the manufacturer.

The belief mechanism to build trust has a positive significant effect on performance $(\beta=.29, \mathrm{p}<.001)$, as stated in our hypothesis $\mathrm{H}_{\mathrm{c}}$. Our result shows that distributors tend to believe in the manufacturer and increase performance. Distributors may be reluctant to share information when they believe the manufacturer is more likely to behave in an untrustworthy manner. The extent to which the manufacturer shares confidential information with its distributor is also a sign of good faith. The result shows that a positive climate in a relationship allows a distributor to perceive reciprocity and mutuality. Through the belief mechanism, distributors appear to increase the engagement of the manufacturer in the relationship and consequently increase performance.

There is no significant impact of the other mechanisms to build trust on the performance measure. The mechanisms of capability $\left(\mathrm{H}_{\mathrm{d}}\right)$, embeddedness $\left(\mathrm{H}_{\mathrm{e}}\right)$ and continuity $\left(\mathrm{H}_{\mathrm{f}}\right)$ showed no significant coefficient. Even though the literature suggests the importance of these mechanisms, we did not find that they have any significant impact on performance. One might suggest that, in the particular relationship studied, the focus is heavily placed on the soft side of trust, where the calculative, affective and belief mechanisms are of importance.

The control variables of dependency and annual turnover do not have a significant effect on performance. The size of the sales force presented a significant negative coefficient $(\beta=-.21, p<.001)$, opposed to previous research about firm size and performance. Most researchers agree that larger firms have become so by virtue of achievement, which suggests a general intention to invest and take some risks. Interestingly, the distributors appear to lose performance as the number of the sales force increases. One possible explanation is the fact that the industry has gone through a wealthy period in areas were distributors' clients are large producers of soybeans. Agribusiness in Brazil faced a great increase in financial results because of the international price of this crop.

\section{CONCLUSION}

The major goal of this study is to investigate the impact of six mechanisms to build up trust on performance. Drawing on the emerging perspective of trust, we developed a central hypothesis stating that the higher the level of the trust mechanisms $\left(\mathrm{H}_{\mathrm{a}}\right.$ : calculative, $\mathrm{H}_{\mathrm{b}}$ : affective, $\mathrm{H}_{\mathrm{c}}$ : belief, $\mathrm{H}_{\mathrm{d}}$ : embeddedness, $\mathrm{H}_{\mathrm{e}}$ : continuity and $\mathrm{H}_{\mathrm{f}}$ : capability), the higher the firm performance. Our empirical testing provided support for hypotheses $\mathrm{H}_{\mathrm{a}}$ (i.e. calculative mechanism), $\mathrm{H}_{\mathrm{b}}$ (i.e. affective mechanism) and $\mathrm{H}_{\mathrm{c}}$ (i.e. belief mechanism).

The findings of our estimated model show that, even though environment leads to suspicion and doubts, managers in the distribution companies seek trust relationships and try to develop trust using a combination of mechanisms to overcome potential problems (e.g. opportunistic behavior) in business relationships. The theoretical discussion and results suggest that the mechanisms by which trust is built are not only based on the calculative dimension. The affective and belief mechanisms appear to play an important role in trust=building efforts. Thus, the results of the survey have provided important evidence to support the theoretical discussions at hand. Overall, trust has proved to be a governance mechanism that efficiently coordinates the activities in the relationship. 
The findings of this paper provide important evidence for the theoretical discussion of trust in business relationships. Our framework of six mechanisms to build trust provides insights into how trust is built. Complementing the literature of transaction cost economics, which solely acknowledges the calculative mechanism, we find evidence for the importance of the social aspects of trust in relationships. Our survey provides deep insights into how trust is generated. Following the theoretical suggestions of Doney and Cannon (1997), this study attempts to measure in the same context six mechanisms to build up trust.

Managers may use our study and its empirical evidence as a check on the adequacy of their existing relationships and the type of mechanism they use to develop trust. Firms should weigh the entire set of important relationships to invest more in the mechanisms that lead to performance. Calculating costs and rewards appear to be relevant to developing trust, though not exclusively. Forecasting a counterpart's behavior and intentions appear to support the belief and affect mechanisms that support the development of trust. The mere effort of calculating and creating the necessary emotional bonds may lead to improved decision making on the parts of managers. It is also important for managers to have accurate perceptions of the impact of trust on performance. We do not mean that managers should develop all relationships based on trust, though the most important may be coordinated by means of trust. Trust is costly to develop and maintain. By considering each of the mechanisms, companies can do business better. If managers either under- or overestimate the positive impact of trust, their efforts will be misguided, eventually dampening performance.

Some limitations of our study must be considered. We used a cross-sectional design, thus preventing the investigation of the dynamic effects of the performance on trust mechanisms. Further work may consider a longitudinal study to investigate the framework at different points in time. In addition, the current study uses the OLS regression model to test the hypothesis. Future research may attempt to estimate the equation based on a multivariate technique such as Structural Equation Modeling. There is also a need to check the causality of the estimated relationships in the model. There might be a possibility that mechanisms influence each other fostering even more performance. Future research may address these impacts. Our study domain was distributors in the Brazilian agrochemical sector. This might limit the generalization of our conclusions. Further research is encouraged to replicate the research in a different setting, such as another country or product. We concentrated our analysis on some elements of performance. Future research can investigate other objective measures of performance.

\section{NOTES}

\footnotetext{
${ }^{1}$ We appreciate the reviewer's warning about a potential generalizability problem in our sample. Most useful was the suggestion on how to test for significant differences across regions.

${ }^{2}$ We first attempted to use Structural Equation Modeling in Lisrel 10.0 to estimate our model and test the hypothesis. Structural equation modeling is a multivariate technique that combines aspects of multiple regression (examining dependence relations) and factor analysis (representing the construct part of multiple variables) to estimate a series of interrelated dependence relations simultaneously (Hair et al., 1998). However, the large number of variables and the relatively small sample size did not allow for the model to be adjusted. The model did not achieve acceptable Goodness of Fit indices given the number of estimated parameters. We therefore decided to test our hypothesis employing Ordinary Least Squared Regression, which is the most commonly used technique in multiple regression analysis (Malhotra, N. K. (1999). Marketing research: an applied orientation. Upper Saddle River: Prentice Hall).
} 


\section{REFERENCES}

Adler, T. R. (2007). Swift trust and distrust in strategic partnering relationships: key considerations. Journal of Business Strategies, 24(2), 105-118.

Anderson, J. C., \& Narus, J. A. (1990). A model of distributor firm and manufacturer firm working partnerships. Journal of Marketing, 54, $42-58$.

Anderson, E., \& Weitz, B. (1989). Determinants of continuity in conventional industrial channel dyads. Market Science, 8(4), 310-323.

Akerlof, G. A. (1970). The market for "lemons": quality uncertainty and the market mechanism. Quarterly Journal of Economics, 84(3), 488-500.

Arrow, K. (1973). Information and Economic Behavior. Stockholm: Federation of Swedish Industry.

Barney, J. B. (1991). Firm resources and sustained competitive advantage. Journal of Management, 17(1), 99-120.

Barney, J. B., \& Hansen, M. H. (1994). Trustworthiness as a source of competitive advantage. Strategic Management Journal, 15(Special Issue), 175-190.

Bradach, J. L., \& Eccles, R. G. (1989). Price, authority and trust: from ideal types to plural forms. Annual Review of Sociology, 15, 97-118.

Coleman, J. S. (1988). Social capital in the creation of human capital. American Journal of Sociology, 94, S95-S120.

Das, T. K., \& Teng, B. (1998). Between trust and control: developing confidence in partner cooperation in alliances. Academy of Management Review, 23(3), 491-512.

Deutsch, M. (1969). Conflicts: productive and destructive. Journal of Social Issues, 25(1), 7-41.

Doney, P. M., \& Cannon, J. P. (1997). An examination of the nature of trust in buyer-seller relationships. Journal of Marketing, 61, 35-51.

Dwyer, F. R., Schurr, P. H., \& Oh, S. (1987). Developing buyer-seller relationships. Journal of Marketing, 51, 11-27.

Ganesan, S. (1994). Determinants of long-term orientation in buyer-seller relationships. Journal of Marketing, 58, 1-19.

Geyskens, I., Steenkamp, J-B. E. M., \& Kumar, N. (1998). Generalizations about trust in marketing channel relationships using meta-analysis. International Journal of Research in Marketing, 15(3), 223-248.

Granovetter, M. (1985). Economic action and social structure: the problem of embeddedness. American Journal of Sociology, 91(3), 481-510.

Gulati, R. (1995). Does familiarity breed trust? The implications of repeated ties for contractual choice in alliances. Academy of Management Journal, 38(1), 85-112.

Hair, J. F., Anderson, R., Tatham, R. L., \& Black, W. C. (1998). Multivariate data analysis. Upper Saddle River: Prentice Hall.

Hakansson, H., \& Snehota, I. (1995). Developing relationships in business network. New York: Routledge. 
Herder, M., \& Brian, J. D. (2008). Canada's stem cell corporation: aggregate concerns and the question of public trust. Journal of Business Ethics, 77(1), 73-84.

Jarillo, J. C. (1988). On strategic networks. Strategic Management Journal, 9(1), 31-41.

Klein, R., Rai, A., \& Straub, D. W. (2007). Competitive and cooperative positioning in supply chain logistics relationships. Decision Science, 38(4), 611-646.

Klein, B. (1996). Why hold-ups occur: the self-enforcing range of contractual relationships. Economic Inquiry, 34, 444-463.

Kumar, N., Scheer, L. K., \& Steenkamp, J-B. E. M. (1995). The effects of perceived interdependence on dealer attitudes. Journal of Marketing Research, 32, 348-356.

Larson, A. (1992). Networks dyads in entrepreneurial settings: a study of the governance of exchange relationships. Administrative Science Quarterly, 37(1), 76-104.

Lewicki, R., Mcallister, D., \& Bies, R. (1998). Trust and distrust: new relationships and realities. Academy of Management Review, 23(3), 438-458.

Lusch, R. F., \& Brown, J. R. (1996). Interdependency, contracting, and relational behavior in market channels. Journal of Marketing, 60, 19-38.

Morgan, R. M., \& Hunt, S. D. (1994). The commitment-trust theory of relationship marketing. Journal of Marketing, 58, 20-38.

Nooteboom, B., Berger, H., \& Noorderhaven, N. G. (1997). Effects of trust and governance on relational risk. Academy of Management Journal, 40(2), 302-308.

Powell, W. W. (1990). Neither market nor hierarchy: network forms of organization. Research in Organizational Behavior, 12, 295-336.

Rousseau, D. M., Sitkin, S. B., Burt, R. S., \& Camerer, C. (1998). Not so different after all: a crossdiscipline view of trust. Academy of Management Review, 23(3), 393-404.

Ring, P. S., \& Van de Ven, A. H. (1992). Structuring cooperative relationships between organizations. Strategic Management Journal, 13(7), 483-498.

Rotter, J. B. (1971). Generalized expectancies for interpersonal trust. American Psychologist, 26(5), 443-452.

Rotter, J. B. (1980). Interpersonal trust, trustworthiness and gullibility. American Psychologist, 35(1), $1-7$.

Smith, J. B., \& Barclay, D. W. (1997). The effects of organizational differences and trust on the effectiveness of selling partner relationships. Journal of Marketing, 61, 3-21.

Sitkin, S. B., \& Roth, N. L. (1993). Explaining the limited effectiveness of legalic 'remedies' for trust/distrust. Organization Science, 4(3), 367-392.

Thorelli, H. B. (1986). Networks: between markets and hierarchies. Strategic Management Journal, $7(1), 37-51$.

Uzzi, B. (1997). Social structure and competition in interfirm networks: the paradox of embeddedness. Administrative Science Quarterly, 42(1), 35-67.

Williamson, O. E. (1993). Calculativeness, trust, and economic organization. Journal of Law, Economics and Organization, 36(1), 453-486. 
Williamson, O. E. (1996). The mechanism of governance. New York: Oxford University Press.

Wicks, A. C., Berman, S. L., \& Jones, T. M. (1999). The structure of optimal trust: moral and strategic implications. Academy of Management Review, 24(1), 99-116.

Zaheer, A., \& Venkatraman, N. (1995). Relational governance as an interorganizational strategy: an empirical test of the role of trust in economic exchange. Strategic Management Journal, 16(5), 373-392.

Zaheer, A., McEvily, B., \& Perrone, V. (1998). Does trust matter? Exploring the effects of interorganizational and interpersonal trust on performance. Organization Science, 9(2), 141159.

Zajac, E. J., \& Olsen, C. P. (1993). From transaction cost to transactional value analysis: implications for the study interorganizational strategies. Journal of Management Studies, 30(1), 131-145.

Zand, D. E. (1972). Trust and managerial problem solving. Administrative Science Quarterly, 17(2), 229-239.

Zylbersztajn, D., \& Zuurbier, P. J. P. (1999). A non-naive explanation of trust: avoiding mistaken decisions for agribusiness chain management [Séries Estudos Temáticos $\mathrm{n}^{\circ}$ 002/99]. Universidade de São Paulo, São Paulo, SP, Brazil. 